\title{
Molecular Characterization of Apple Cultivars in Japan by $S$-RNase Analysis and SSR Markers
}

\author{
Kentaro Kitahara and Shogo Matsumoto ${ }^{1}$ \\ Department of Biology, Faculty of Education, Gifu University, Gifu 501-1193, Japan
}

Toshiya Yamamoto and Junichi Soejima

National Institute of Fruit Tree Science, Tsukuba, Ibaraki 305-8605, Japan

Tetsuya Kimura

National Center for Seeds and Seedlings, Tsukuba, Ibaraki 305-0852, Japan

Hiromitsu Komatsu

Nagano Fruit Tree Experiment Station, Nagano 382-0072, Japan

\author{
Kazuyuki Abe \\ Department of Apple Research, National Institute of Fruit Tree Science, Morioka 020-0123, Japan
}

\begin{abstract}
AdDitional INDEX wORDs. Malus $\times$ domestica, microsatellites, molecular diversity, parentage analysis, simple sequence repeat, $S$-allele

Aвstract. We examined the genetic diversity and relatedness among apple (Malus $\times$ domestica Borkh.) cultivars in Japan. The 42 apple cultivars, including major cultivars in Japan, were divided into five groups based on SSR genotypes. Most economically important cultivars belong in three groups: Fuji-Delicious, Golden Delicious, and Jonathan groups, and their genetic backgrounds seemed to be narrow. We also investigated the parent-offspring relationships of nine apple cultivars. 'Jonathan', 'Fuji', and 'Rero 11' were identified as the respective paternal parents of three cultivars described as having unknown paternal parents (i.e., 'Akagi', 'Ambitious', and 'Hokuto'). 'Starking Delicious', 'Senshu', and 'Golden Delicious', rather than 'Ralls Janet', 'Hatsuaki', and 'Indo', seemed to be the paternal parents of 'Kinsei', 'Kiou', and 'Mellow', respectively. 'Carolina Red June' was excluded as a paternal parent of 'Ranzan'. Both attributed parents of 'Scarlet' ('Akane' and 'Starking Delicious') were excluded, and it was suggested that 'Fuji' was used as either a maternal or a paternal parent of 'Scarlet'. 'Jonathan' rather than 'McIntosh' seems to be a maternal parent of 'Yukari'.
\end{abstract}

The apple industry in Japan developed following the importation of 75 cultivars from the United States in 1871. The major cultivars in Japan evolved from 'Ralls Janet' and 'Jonathan' in the 1960s to early 1970s to 'Starking Delicious' in the 1970s. Then, 'Fuji' replaced them, and is today the leading cultivar in Japan (Soejima et al., 2000). 'Fuji' was produced by 'Ralls Janet' $x$ 'Delicious'. Other main cultivars are 'Tsugaru' for the early season (produced by 'Golden Delicious' $x$ 'Jonathan'), 'Jonagold' for the mid-season (produced by 'Golden Delicious' $x$ 'Jonathan'), and 'Orin' for the late season (produced by 'Golden Delicious' $x$ 'Indo'). As a limited number of cultivars were used reproducibly as parents for the breeding of major cultivars in Japan, those cultivars might be characterized by a narrow genetic origin with limited genetic diversity.

Apples have a gametophytic self-incompatibility (GSI) that is due to the failure of pollen tube growth in the style when the pollen shares the same $S$-haplotype with the pistil (de Nettancourt, 1977). GSI enforces outbreeding and results in heterozygosity. To date, we have investigated the $S$-genotypes of more than 350 apple cultivars, lineages, and species by the PCR-digestion

Received for publication 9 Mar. 2005. Accepted for publication 13 May 2005. We wish to thank Mr. K. Sato for offering useful suggestions. We are also indebted to Mr. T. Eguchi for his technical assistance. This research was supported by a Grant-in-Aid for Scientific Research from the Ministry of Education, Culture, Sports, Science and Technology of Japan (Nos. 14360019 and 15208004).

${ }^{1}$ Corresponding author: Dr. Shogo Matsumoto, Department of Biology, Faculty of Education, Gifu University, Yanagido, Gifu 501-1193, Japan. Phone: +81-58293-2257; fax: +81-58-293-2207; e-mail: shmatsum@cc.gifu-u.ac.jp method developed based on the polymorphism of an $S$-locus gene in the pistil (Broothaerts et al., 1995; Janssens et al., 1995; Kitahara and Matsumoto, 2002a, 2002b; Kitahara et al., 2000; Matsumoto and Kitahara, 2000; Matsumoto et al., 1999a, 1999b; Verdoodt et al., 1998). The gene encoding ribonuclease is called $S$-RNase. Having found that the pedigrees of some cultivars were uncertain due to discrepancies in the inheritance of an $S$-RNase allele, we established or corrected those pedigrees by the analysis of simple sequence repeats [SSRs (also called microsatellites)] (Kitahara et al., 2005).

SSRs have become the accepted markers of plant species, and have been found suitable for the assessment of genetic diversity within species and of genetic relationships among species (Gianfranceschi et al., 1998; Gupta et al., 1996; Martinez-Gomez et al., 2003). SSRs have also been used as genetic markers for parentage analyses in grapes (Vitis vinifera L.) (Bowers and Meredith, 1997; Bowers et al., 1999; Sefc et al., 1997, 1998), peaches [Prunus persica (L.) Batsch.] (Testolin et al., 2000; Yamamoto et al., 2003), and pears [Pyrus pyrifolia (Burm.) Nakai] (Kimura et al. 2003). In apples, SSR markers have been used for the molecular characterization and identification of cultivars and for genetic mapping. For instance, Guilford et al. (1997) used three SSR markers for differentiation among 21 cultivars. Gianfranceschi et al. (1998) and Hokanson et al. (1998, 2001) developed 16 and eight SSRs, respectively, to distinguish cultivars, identify cultivar synonyms and misidentified accessions, estimate genetic diversity, and identify genetic relationships among cultivars. The genetic linkage maps of the apple have 
been constructed using SSR markers (Gianfranceschi et al., 1998; Hemmat et al., 2003; Liebhard et al., 2002, 2003; Maliepaard et al., 1998). Previously, we analyzed 19 SSR markers of 22 apple cultivars for the parent identification of eight apple cultivars (Kitahara et al., 2005). It is important for the development of efficient apple-breeding programs to accurately determine parent-offspring relationships.

In this study, we analyzed 19SSR markers of another 20 apple cultivars to establish the genetic relatedness among cultivars and for the parent identification of nine apple cultivars. We also analyzed $S$-RNase allele genotypes of some apple cultivars relating to the parent identification and having apetalous flowers.

\section{Materials and Methods}

Plant material. We used 42 apple cultivars to analyze genetic relatedness and parent-offspring relationships. All Malus Mill. plants used in this study were from collections at the Apple Research Center of the National Institute of Fruit Tree Science, Tsukuba, Japan, or the Nagano Fruit Tree Experiment Station, Nagano, Japan. Young leaves were collected and stored at -80 ${ }^{\circ} \mathrm{C}$ until use.

$\boldsymbol{S}$-Allele SPecific PCR-digestion analysis. Total DNA from the leaves of individual plants was isolated as described by Thomas et al. (1993). The primers and conditions used for the $S$-allele-specific PCR amplification and digestion were essentially those described by Broothaerts et al. (1995) ( $S 2$ - and $S 3$-allele), Janssens et al. (1995) (S7- and S9-allele), Kitahara et al. (2000) (S24-allele), Kitahara and Matsumoto (2002a) (S10-allele), Kitahara and Matsumoto (2002b) (S25-allele), Matsumoto et al. (1999a) (S5- and S7-allele), Matsumoto et al. (1999b) (S1- and $S 20$-allele), Matsumoto and Kitahara (2000) (S28-allele), and Verdoodt et al. (1998) (S4-, S26- and S16(=27)-allele).

SSR AMPLIFICATION OF 19 SSR PRIMER PAIRS. CH01c06, CH01d08, CH01d09, CH01f03b, CH01f07a, CH01g05, $\mathrm{CH} 02 \mathrm{~b} 07, \mathrm{CH} 02 \mathrm{c02b}, \mathrm{CH} 02 \mathrm{c09}, \mathrm{CH} 02 \mathrm{d08}, \mathrm{CH} 02 \mathrm{~g} 04, \mathrm{CH} 03 \mathrm{aO} 4$, $\mathrm{CH03a09,} \mathrm{CH03d07,} \mathrm{CH03d12,} \mathrm{CH03e03,} \mathrm{CH05a04,} \mathrm{CH05c04,}$ and $\mathrm{CH} 05 \mathrm{~g} 08$ were used for the genotyping of apple cultivars (Liebhard et al., 2002). The reaction to DNA amplification was conducted in a $20-\mu \mathrm{L}$ mixture consisting of $10 \mathrm{ng}$ of genomic DNA, $10 \mathrm{~mm}$ Tris- $\mathrm{HCl}$ ( $\mathrm{pH} \mathrm{8.3),} 50 \mathrm{~mm} \mathrm{KCl,} 1.5 \mathrm{~mm} \mathrm{MgCl}_{2}$, $0.01 \%$ gelatin, $200 \mu \mathrm{M}$ each deoxynucleotides, $0.5 \mu \mathrm{M}$ each of three forward primers labeled with a fluorescent chemical (FAM, VIC, or NED) in addition to an unlabelled reverse primer, and one unit of Taq DNA polymerase (Applied Biosystems, Foster City, Calif.). The analysis was programmed in a thermal cycler (GeneAmp 2700 apparatus; Applied Biosystems) and conducted under the following conditions: $5 \mathrm{~min}$ preheating at $94^{\circ} \mathrm{C}, 1 \mathrm{~min}$ at $94{ }^{\circ} \mathrm{C}, 1 \mathrm{~min}$ at $55^{\circ} \mathrm{C}$, and $2 \mathrm{~min}$ at $72^{\circ} \mathrm{C}$. The PCR products were separated and detected using a PRISM 310 DNA sequencer (Applied Biosystems). The size of the amplified bands was calculated based on an internal standard DNA (GeneScan 400HD Rox; Applied Biosystems) with GeneScan software (Applied Biosystems).

Statistical analysis. The observed heterozygosity was calculated as the number of heterozygous genotypes at a given locus divided by the total number of genotypes scored at that locus. The number of expected heterozygous genotypes was calculated based on the frequency of each genotype according to the formula: $\mathrm{He}=1-\sum p i^{2}$, where $p i$ is the frequency of the $i^{\text {th }}$ allele of each SSR locus. A phenogram of 42 cultivars was constructed using the unweighted pair-group method using arithmetic averages (UPGMA) based on Nei's genetic identity (Nei, 1972). The program NTSYS-pc, version 2.1 was used to construct the phenogram (Rohlf, 2000).

\section{Results and Discussion}

Molecular diversity of apPle Cultivars in JaPAN. The number of alleles per locus ranged from four for $\mathrm{CH} 02 \mathrm{cO} 2 \mathrm{~b}$ and $\mathrm{CH} 05 \mathrm{c0} 4$ to nine for $\mathrm{CH03a04}, \mathrm{CH} 03 \mathrm{~d} 07$, and $\mathrm{CH05a04}$, giving an average number of 6.6 (Table 1 ). The observed heterozygosity (Ho) for individual loci ranged from 0.35 for $\mathrm{CH} 05 \mathrm{~g} 08$ to 0.90 for $\mathrm{CH} 01 \mathrm{c06}$ with an average respective value of 0.72 (Table 1). The expected heterozygosity $(\mathrm{He})$ for individual loci ranged from 0.49 for $\mathrm{CH} 05 \mathrm{~g} 08$ to 0.81 for $\mathrm{CH} 02 \mathrm{~d} 08$ with an average respective value of 0.71 (Table 1). Genetic relatedness among 42 apple cultivars was examined based on SSR genotypes. The dendrogram generated from the UPGMAcluster analysis enabled us to identify five major groups and one individual cultivar (Fig. 1). The first group, corresponding to 'Fuji' through 'Empire' (Fuji-Delicious group), is comprised of all cultivars with at least one-half 'Fuji' or 'Delicious' in their pedigrees except for 'Ralls Janet'. Since 'Ralls Janet' and 'Delicious' were used as the maternal and the paternal parent of 'Fuji', respectively, both must be close to 'Fuji' genetically. The second group, corresponding to 'Orin' through 'Ranzan'(Golden Delicious group), includes all cultivars that have at least one-quarter 'Golden Delicious' in their pedigrees, except for 'Indo', 'Yellow Newtown Pippin', and 'Ranzan'. 'Indo' and 'Yellow Newtown Pippin' seem to be close to 'Golden Delicious' genetically. We will discuss 'Ranzan' further below. The third group, corresponding to 'Yoko' through 'Jonathan' (Jonathan group), is made up of all cultivars with at least one-half 'Jonathan' in their pedigrees. The fourth group, corresponding to 'Spencer

Table 1. 19 SSR loci used for characterization of 40 apple cultivars as shown in Fig. 1 (we did not use triploid cultivars Hokuto or Mutsu). Observed heterozygosity (Ho) was calculated by division of the individuals showing heterozygous type by total number of individuals. Expected heterozygosity $(\mathrm{He})$ was calculated using the formula $\mathrm{He}=1-\sum p i^{2}$, where $p i$ is the frequency of the $i^{\text {th }}$ allele of each SSR locus.

\begin{tabular}{lrccc}
\hline SSR & $\begin{array}{c}\text { Range of } \\
\text { product } \\
\text { locus }\end{array}$ & $\begin{array}{c}\text { Putative } \\
\text { alleles } \\
\text { (no.) }\end{array}$ & $\begin{array}{c}\text { Observed } \\
\text { heterozygosity } \\
\text { (Ho) }\end{array}$ & $\begin{array}{c}\text { Expected } \\
\text { heterozygosity } \\
\text { (He) }\end{array}$ \\
\hline CH05g08 & $173-180$ & 5 & 0.35 & 0.49 \\
CH03e03 & $186-206$ & 5 & 0.78 & 0.73 \\
CH02c02b & $112-126$ & 4 & 0.41 & 0.62 \\
CH03a04 & $90-124$ & 9 & 0.85 & 0.73 \\
CH03a09 & $131-143$ & 6 & 0.73 & 0.72 \\
CH03d07 & $185-228$ & 9 & 0.80 & 0.77 \\
CH03d12 & $108-146$ & 6 & 0.55 & 0.52 \\
CH01c06 & $156-188$ & 6 & 0.90 & 0.78 \\
CH01f03b & $139-179$ & 5 & 0.80 & 0.70 \\
CH01f07a & $178-206$ & 7 & 0.80 & 0.77 \\
CH02b07 & $103-126$ & 7 & 0.73 & 0.71 \\
CH02d08 & $212-254$ & 8 & 0.88 & 0.81 \\
CH01d09 & $130-176$ & 8 & 0.63 & 0.80 \\
CH05c04 & $186-210$ & 4 & 0.58 & 0.56 \\
CH01g05 & $140-174$ & 7 & 0.73 & 0.70 \\
CH01d08 & $238-292$ & 6 & 0.80 & 0.77 \\
CH02c09 & $233-259$ & 7 & 0.85 & 0.80 \\
CH05a04 & $159-212$ & 9 & 0.85 & 0.80 \\
CH02g04 & $187-196$ & 7 & 0.63 & 0.64 \\
\hline
\end{tabular}




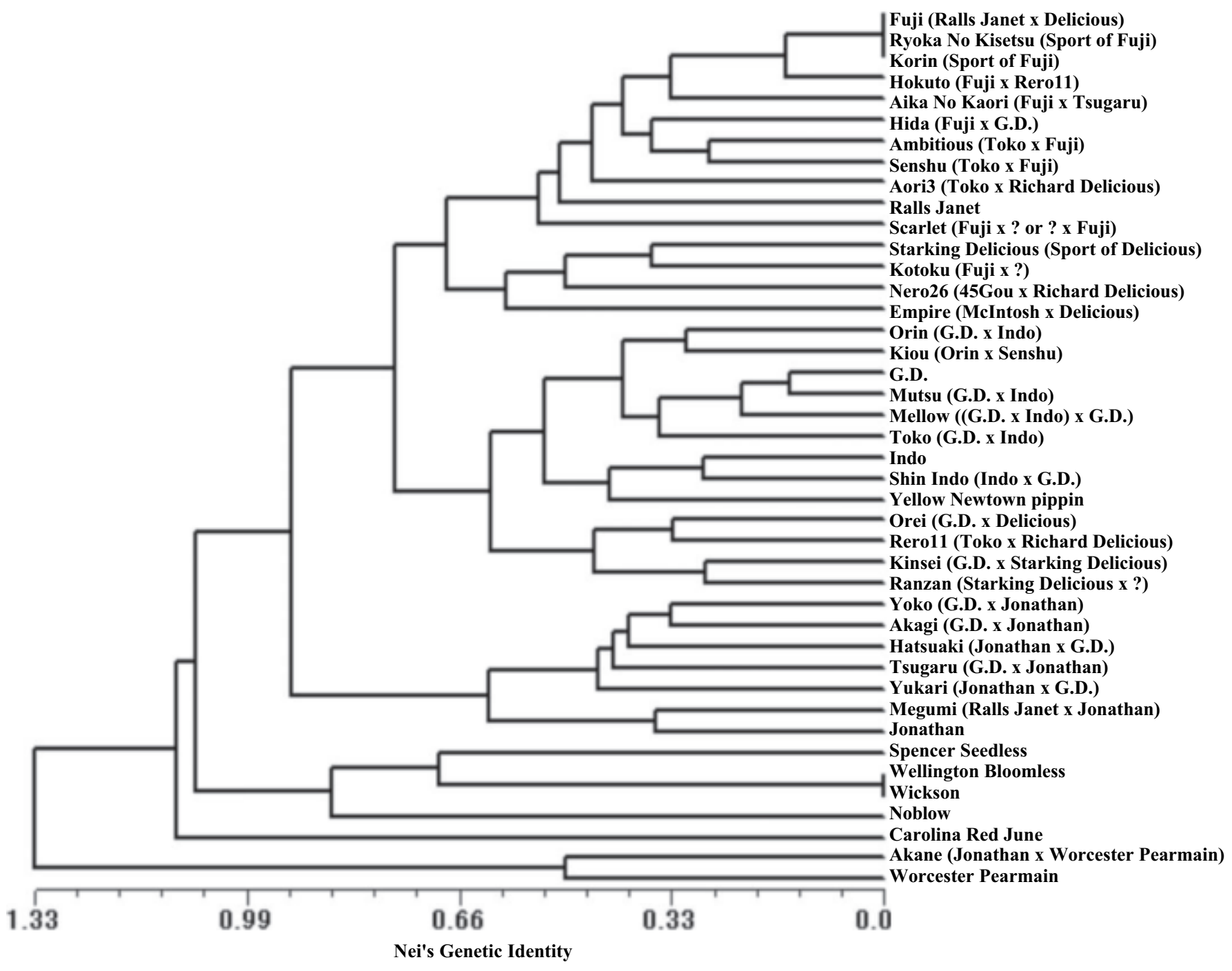

Fig. 1. Phenogram for the 42 apple cultivars evaluated in this study. The phenogram was produced based on SSR genotypes from 19 SSR loci using the UPGMA method of Nei's genetic identity between the cultivars. Parents of the cultivars are in parentheses; G.D. = 'Golden Delicious'.

Seedless' through 'Noblow', is comprised of all cultivars having apetalous flowers with the development of parthenocarpic fruits. We identified only the $S 3$-RNase allele from both 'Wellington Bloomless' and 'Wickson', while the $S$-RNase allele genotypes of 'Spencer Seedless' and 'Noblow' were identified as S1S9 and S4S24, respectively. All 38 alleles from the 19 SSR loci in 'Wellington Bloomless' and 'Wickson' were completely identical, strongly suggesting that both might be either genetically close or the same cultivar. The observed dendrogram based on SSR analysis revealed close genetic relationships among 'Spencer Seedless', 'Noblow', 'Wellington Bloomless', and 'Wickson'. The fifth group is 'Akane' and 'Worcester Pearmain' (Fig. 1). The paternal parent of 'Akane' is 'Worcester Pearmain'.

Since one allele of the parent was tranmitted to its progeny, these results were quite reasonable. The dendrogram might make it possible to know which parent is genetically closer to the cultivar. For instance, 'Aika No Kaori' and 'Hida' are closer to the maternal parent 'Fuji' than to the paternal parents 'Tsugaru' and 'Golden Delicious' (Fig. 1). Also, 'Yoko', 'Hatsuaki', and 'Tsugaru' are closer to 'Jonathan' than to 'Golden Delicious', while 'Akane' is closer to 'Worcester Pearmain' than to 'Jonathan' (Fig. 1). The similarity will be relative to the loci that we test. Almost all SSR alleles among apple cultivars in Japan were not unique. Since only limited numbers of cultivars have been used as progenitors in breeding programs, we ought to be using different cultivars for an expansion of the genetic base.

Parentage analysis of 'Akagi', 'Ambitious', 'Hokuto', 'Kinsei', 'Kiou', 'Mellow', 'RanZan', 'Scarlet', AND 'Yukari'. 'Akagi' and 'Ambitious' are chance seedlings of 'Golden Delicious' $x$ an unknown paternal parent, and 'Toko' $x$ an unknown paternal parent, respectively. 'Jonathan' (S7S9) and 'Fuji' (S1S9) have likely been used as paternal parents of 'Akagi' (S3S7) and 'Ambitious' (S2S9), respectively, based on $S$-RNase content of them and the maternal parents, 'Golden Delicious (S2S3) and 'Toko' (S2S7) (Table 2), and fruit and branch characteristics. Thirty-eight alleles in 'Akagi' and 'Ambitious' have been inherited from 'Golden Delicious' and 'Jonathan', and 'Toko' and 'Fuji', respectively, without discrepancy, indicating that 'Akagi' and 'Ambitious' are hybrids of those two cultivars (Tables 3, 4). The fact that 'Jonathan' and 'Fuji' were used as the paternal parents of 'Akagi' and 'Ambitious', respectively, is also supported by the phenogram results (Fig. 1). 
Table 2. S-RNase allele genotypes and breeding process of 30 apple cultivars. Only the cultivars with parentage questions and having apetalous flowers were selected.

\begin{tabular}{|c|c|c|c|}
\hline Cultivar & $\begin{array}{c}S \text {-RNase } \\
\text { allele } \\
\text { genotypes }\end{array}$ & References & $\begin{array}{l}\text { Breeding process of the cultivars } \\
\text { relating to parental questions }\end{array}$ \\
\hline Wellington Bloomless & S3? & This work & \\
\hline Wickson & S3? & This work & \\
\hline Spencer Seedless & S1S9 & This work & \\
\hline Noblow & $S 4 S 24$ & This work & \\
\hline Akagi & S3S7 & Matsumoto et al., 1999a & Sown in 1962, selected in 1969, named in 1973 \\
\hline Ambitious & $S 2 S 9$ & Kitahara et al., 2000 & $\begin{array}{l}\text { Sown and selected in } 1971-73 \text {, selected in } 1981 \text {, registered in } \\
1985\end{array}$ \\
\hline Golden Delicious & $S 2 S 3$ & Janssens et al., 1995 & Introduced into Japan in 1923 \\
\hline Toko & $S 2 S 7$ & Matsumoto et al., 1999b & $\begin{array}{l}\text { 'Golden Delicious' was crossed with 'Indo' in 1930, fruited in } \\
\text { 1938, named in } 1962\end{array}$ \\
\hline Jonathan & 5759 & Matsumoto et al., 1999a & Introduced into Japan in 1871 \\
\hline Fuji & S1S9 & Matsumoto et al., 1999a & $\begin{array}{l}\text { 'Ralls Janet' was crossed with 'Delicious' in } 1939 \text {, selected in } \\
\text { 1958, registered in } 1962\end{array}$ \\
\hline Hokuto & S1S7S9 & Sakurai et al., 2000 & Selected in 1980, registered in 1983 \\
\hline Redspur Delicious & $S 9 S 28^{z}$ & Matsumoto and Kitahara, 2000 & Introduced into Japan in 1960 \\
\hline Starkrimson Delicious & $S 9 S 28^{z}$ & Matsumoto and Kitahara, 2000 & $\begin{array}{l}\text { Discovered in 1953, registered in 1957, introduced into Japan } \\
\text { in } 1960\end{array}$ \\
\hline Aori 3 & $S 2 S 28$ & This work & $\begin{array}{l}\text { 'Toko' was crossed with 'Richared Delicious' in 1952, selected } \\
\text { in 1963, named in } 1970\end{array}$ \\
\hline Rero 11 & $S 7 S 28$ & This work & $\begin{array}{l}\text { 'Toko’ was crossed with 'Richared Delicious' in 1952, } \\
\text { published in } 1967\end{array}$ \\
\hline Kinsei & $S 2 S 9$ & Matsumoto et al., 1999a & Fruited in 1962, named in 1968, registered in 1972 \\
\hline Ralls Janet & S1S2 & Matsumoto et al., 1999a & Introduced into Japan in 1871 \\
\hline Kiou & S1S7 & Matsumoto et al., 2003a & Sown in 1984, selected in 1988, registered in 1994 \\
\hline Orin & $S 2 S 7$ & Sakurai et al., 1997 & 'Golden Delicious' was crossed with 'Indo', named in 1952 \\
\hline Hatsuaki & S3S9 & Matsumoto et al., 1999a & $\begin{array}{l}\text { 'Jonathan' was crossed with 'Golden Delicious' in } 1939 \text {, } \\
\text { selected in } 1959, \text { named and registered in } 1976\end{array}$ \\
\hline Senshu & S1S7 & Matsumoto et al., 1999b & $\begin{array}{l}\text { 'Toko' was crossed with 'Fuji' in 1966, selected in } 1974, \\
\text { named in } 1978 \text {, registered in } 1980\end{array}$ \\
\hline Mellow & $S 2 S 3$ & Matsumoto et al., 2003a & Selected in 1973, registered in 1990 \\
\hline Indo & $S 7 S 20$ & Matsumoto et al., $1999 \mathrm{~b}$ & Sown in 1875 , the first cultivar produced in Japan \\
\hline Ranzan & $S 2 S 9$ & This work & Registered in 1985 \\
\hline Starking Delicious & S9S28 & Matsumoto and Kitahara, 2000 & Introduced into Japan in 1929 \\
\hline Carolina Red June & S3S10 & This work & Introduced into Japan in 1907 \\
\hline Scarlet & S3S9 & Matsumoto et al., 2003b & $\begin{array}{l}\text { 'Akane' was crossed with 'Starking Delicious' in } 1970 \text {, } \\
\text { selected in } 1973 \text {, registered in } 1984\end{array}$ \\
\hline Akane & $S 7 S 24$ & Kitahara et al., 2000 & $\begin{array}{l}\text { 'Jonathan' was crossed with 'Worcester Pearmain' in 1939, } \\
\text { registered in } 1970\end{array}$ \\
\hline Yukari & $S 2 S 9$ & Matsumoto et al., 2003b & $\begin{array}{l}\text { 'McIntosh' was crossed with 'Golden Delicious' in 1970, } \\
\text { selected in } 1975 \text {, registered in } 1986\end{array}$ \\
\hline McIntosh & S10S25 & Kitahara and Matsumoto, 2002a, b & Introduced into Japan in 1890 \\
\hline
\end{tabular}

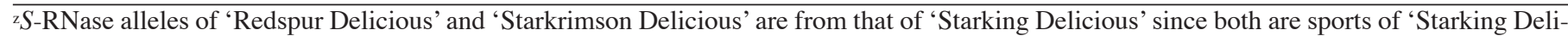
cious'.

Previously, we excluded 'Mutsu' as the paternal parent of 'Hokuto', but could not find a true paternal parent since the parental candidates 'Indo' and 'Shin Indo' were excluded as the paternal parent of 'Hokuto' by SSR markers (Kitahara et al., 2005). We selected 'Redspur Delicious' (a sport of 'Starking Delicious'), 'Starkrimson Delicious' (a sport of 'Starking Delicious'), 'Aori 3', and 'Rero 11' as the remaining candidate for the paternal parent of 'Hokuto' from the breeding register. From the $S$-RNase content of 'Hokuto' (S1S7S9) and its maternal parent, 'Fuji' (S1S9), Rero 11 (S7S28) rather than 'Redspur Delicious' (a sport of 'Starking Delicious' S9S28), 'Starkrimson Delicious' (a sport of 'Starking Delicious' S9S28), and 'Aori 3' (S2S28) seemed to be the paternal parent of 'Hokuto' (Table
2). We investigated 19 SSR loci to confirm the paternal parent of 'Hokuto'. All 57 alleles in 'Hokuto' have been inherited from 'Fuji' (38 alleles) and 'Rero 11' (19 alleles) without discrepancy, confirming that 'Hokuto' is a hybrid of both those cultivars (Tables 3,4). The UPGMA cluster analysis data confirmed that 'Hokuto' belonged to the Fuji-Delicious group, while 'Rero 11' belonged to the Golden Delicious group (Fig. 1). The dendrogram reveals genetic similarity, but not family pedigree. 'Hokuto' is a triploid, and the $2 \mathrm{n}$ and $\mathrm{n}$ gametes are contributed by the maternal parent 'Fuji' and the paternal parent 'Rero 11', respectively. Since 'Hokuto' seems to be genetically closer to 'Fuji' than to 'Rero 11', 'Hokuto' might belong to the Fuji-Delicious group. 
Table 3. SSR genotypes of 22 apple cultivars analyzed using 19 SSR loci. Only the cultivars having parentage questions were selected. SSR genotypes are denoted by a combination of two or three putative alleles indicated by their size (bp).

\begin{tabular}{|c|c|c|c|c|c|}
\hline \multirow[b]{2}{*}{ Cultivar } & \multicolumn{5}{|c|}{ SSR genotype (bp) } \\
\hline & $\mathrm{CH} 05 \mathrm{~g} 08$ & $\mathrm{CH} 03 \mathrm{e} 03$ & $\mathrm{CH} 02 \mathrm{c} 02 \mathrm{~b}$ & $\mathrm{CH} 03 \mathrm{a} 04$ & $\mathrm{CH} 03 \mathrm{a} 09$ \\
\hline Golden Delicious ${ }^{z}$ & $175 / 175$ & $200 / 204$ & $116 / 122$ & $124 / 124$ & $131 / 135$ \\
\hline Akagi & $175 / 175$ & $204 / 206$ & $112 / 116$ & $100 / 124$ & $135 / 143$ \\
\hline Jonathan ${ }^{z}$ & $175 / 179$ & $198 / 206$ & $112 / 112$ & $100 / 116$ & $131 / 143$ \\
\hline Toko ${ }^{z}$ & $175 / 175$ & $186 / 204$ & $112 / 122$ & $120 / 124$ & $131 / 139$ \\
\hline Ambitious & $175 / 175$ & $186 / 198$ & $112 / 116$ & $124 / 124$ & $131 / 131$ \\
\hline Fuji $^{z}$ & $175 / 175$ & $186 / 198$ & $112 / 116$ & $94 / 124$ & $131 / 131$ \\
\hline Hokuto $^{z}$ & $175 / 175 / 175$ & $186 / 198 / 204$ & $112 / 116 /$ & $94 / 124 /$ & $131 / 135 /$ \\
\hline Rero 11 & $175 / 175$ & $204 / 204$ & $112 / 112$ & $96 / 124$ & $135 / 139$ \\
\hline Kinsei & $175 / 175$ & $186 / 204$ & $116 / 116$ & $96 / 124$ & $131 / 135$ \\
\hline Ralls Janet & $175 / 175$ & $186 / 198$ & $112 / 122$ & $94 / 124$ & $131 / 135$ \\
\hline Starking Deliciousz & $175 / 179$ & $186 / 204$ & $112 / 116$ & $96 / 124$ & $131 / 135$ \\
\hline Orinz & $175 / 175$ & $200 / 200$ & $112 / 122$ & $124 / 124$ & $135 / 139$ \\
\hline Kiou & $175 / 175$ & $186 / 200$ & $112 / 122$ & $94 / 124$ & $131 / 139$ \\
\hline Hatsuaki & $175 / 179$ & $200 / 206$ & $112 / 122$ & $100 / 124$ & $135 / 143$ \\
\hline Senshu & $175 / 175$ & $186 / 204$ & $112 / 112$ & $94 / 120$ & $131 / 139$ \\
\hline Mellow & $175 / 175$ & $200 / 204$ & $112 / 122$ & $124 / 124$ & $131 / 131$ \\
\hline Indo $^{z}$ & $175 / 179$ & $186 / 200$ & $112 / 112$ & $120 / 124$ & $131 / 139$ \\
\hline Ranzan & $179 / 179$ & $186 / 204$ & $116 / 116$ & $96 / 124$ & $135 / 135$ \\
\hline Carolina Red June & $173 / 179$ & $186 / 186$ & $116 / 122$ & $124 / 124$ & $133 / 141$ \\
\hline Akane & $173 / 175$ & $198 / 206$ & $112 / 116$ & $100 / 116$ & $131 / 135$ \\
\hline Scarlet & $175 / 180$ & $186 / 186$ & $112 / 122$ & $94 / 124$ & $131 / 141$ \\
\hline \multirow[t]{2}{*}{ Yukari } & $175 / 175$ & $198 / 204$ & $112 / 116$ & $100 / 124$ & $131 / 135$ \\
\hline & \multicolumn{5}{|c|}{ SSR genotype (bp) } \\
\hline Cultivar & $\mathrm{CH} 03 \mathrm{~d} 07$ & CH03d12 & $\mathrm{CH01c06}$ & CH01f03b & CH01f07a \\
\hline Golden Delicious & $188 / 206$ & $124 / 124$ & $156 / 162$ & $139 / 171$ & $178 / 198$ \\
\hline Akagi & $188 / 202$ & $124 / 124$ & $162 / 188$ & $171 / 171$ & $178 / 194$ \\
\hline Jonathan & $202 / 206$ & $124 / 124$ & $188 / 188$ & $171 / 171$ & $194 / 196$ \\
\hline Toko & $188 / 218$ & $124 / 124$ & $162 / 188$ & $139 / 177$ & $178 / 178$ \\
\hline Ambitious & $188 / 226$ & $124 / 124$ & $160 / 162$ & $139 / 179$ & $178 / 206$ \\
\hline Fuji & $226 / 226$ & $116 / 124$ & $158 / 160$ & $171 / 179$ & $178 / 206$ \\
\hline Hokuto & $188 / 226 /$ & $116 / 124 /$ & $158 / 160 / 162$ & $171 / 177 / 179$ & $178 / 206 /$ \\
\hline Rero 11 & $188 / 206$ & $124 / 124$ & $160 / 162$ & $177 / 179$ & $178 / 198$ \\
\hline Kinsei & $188 / 206$ & $116 / 124$ & $160 / 162$ & $139 / 139$ & $178 / 206$ \\
\hline Ralls Janet & $226 / 226$ & $116 / 124$ & $156 / 158$ & $171 / 171$ & $178 / 190$ \\
\hline Starking Delicious & $206 / 226$ & $116 / 124$ & $160 / 160$ & $139 / 179$ & $198 / 206$ \\
\hline Orin & $206 / 226$ & $124 / 124$ & $162 / 188$ & $139 / 177$ & $196 / 198$ \\
\hline Kiou & $188 / 226$ & $116 / 124$ & $162 / 162$ & $139 / 177$ & $178 / 196$ \\
\hline Hatsuaki & $188 / 202$ & $124 / 124$ & $162 / 188$ & $171 / 171$ & $178 / 196$ \\
\hline Senshu & $188 / 226$ & $116 / 124$ & $158 / 162$ & $139 / 179$ & $178 / 178$ \\
\hline Mellow & $188 / 206$ & $124 / 124$ & $160 / 162$ & $171 / 177$ & $178 / 198$ \\
\hline Indo & $218 / 226$ & $116 / 124$ & $160 / 188$ & $177 / 179$ & $178 / 196$ \\
\hline Ranzan & $188 / 206$ & $124 / 124$ & $156 / 160$ & $139 / 171$ & $178 / 206$ \\
\hline Carolina Red June & $206 / 226$ & $116 / 122$ & $162 / 162$ & $171 / 171$ & $194 / 196$ \\
\hline Akane & $186 / 206$ & $124 / 146$ & $156 / 188$ & $139 / 171$ & $194 / 194$ \\
\hline Scarlet & $206 / 226$ & $122 / 124$ & $160 / 162$ & $171 / 179$ & $178 / 194$ \\
\hline Yukari & $188 / 202$ & $124 / 124$ & $156 / 188$ & $171 / 171$ & $194 / 198$ \\
\hline
\end{tabular}

Table 3 continued on next page.

'Kinsei', 'Kiou', 'Mellow', and 'Ranzan' were produced by 'Golden Delicious' $x$ 'Ralls Janet' in 1954, 'Orin' x 'Hatsuaki' in 1983, '19Gou' ('Golden Delicious' crossed with 'Indo') x 'Indo' in 1958, and 'Starking Delicious' $x$ 'Carolina Red June' in 1955, respectively. However, the $S$-RNase contents of 'Kinsei' (S2S9), 'Kiou' (S1S7), Mellow (S2S3), and 'Ranzan' (S2S9) did not match any of the expected $S$-RNase contents from their reported parents, 'Golden Delicious' (S2S3) x 'Ralls Janet' (S1S2), 'Orin' (S2S7) x 'Hatsuaki' (S3S9), '19Gou' ['Golden Delicious' (S2S3) x 'Indo' (S7S20)] x 'Indo' (S7S20), and 'Starking Delicious' (S9S28) x
'Carolina Red June' (S3S10), respectively (Table 2). Previously, we confirmed their $S$-genotypes by pollination tests (Matsumoto et al., 1999a, 2003b, unpublished results), which suggested that some other paternal (or maternal in the case of 'Kinsei') parents possessing the $S 9, S 1, S 2$ (or $S 3$ ), and $S 2$ might have been used to produce 'Kinsei', 'Kiou', 'Mellow', and 'Ranzan', respectively. We selected 'Starking Delicious', 'Senshu', 'Golden Delicious', and 'Golden Delicious' (or 'Ralls Janet') as the parents of 'Kinsei', 'Kiou', 'Mellow', and 'Ranzan', respectively, from their $S$-RNase 
Table 3. Continued from previous page.

\begin{tabular}{|c|c|c|c|c|c|}
\hline \multirow[b]{2}{*}{ Cultivar } & \multicolumn{5}{|c|}{ SSR genotype (bp) } \\
\hline & $\mathrm{CH} 02 \mathrm{~b} 07$ & $\mathrm{CH} 02 \mathrm{~d} 08$ & CH01d09 & $\mathrm{CH} 05 \mathrm{c} 04$ & CH01g05 \\
\hline Golden Delicious & $103 / 111$ & $222 / 224$ & $132 / 134$ & $186 / 200$ & $140 / 146$ \\
\hline Akagi & $103 / 126$ & $224 / 254$ & $134 / 134$ & $186 / 186$ & $140 / 144$ \\
\hline Jonathan & $105 / 126$ & $228 / 254$ & $134 / 134$ & $186 / 186$ & $144 / 144$ \\
\hline Toko & $103 / 111$ & $224 / 228$ & $130 / 132$ & $186 / 200$ & $140 / 157$ \\
\hline Ambitious & $103 / 105$ & $212 / 228$ & $130 / 148$ & $186 / 200$ & $140 / 140$ \\
\hline Fuji & $105 / 105$ & $212 / 212$ & $148 / 148$ & $186 / 208$ & $140 / 144$ \\
\hline Hokuto & $103 / 105 /$ & $212 / 212 / 212$ & $130 / 148 /$ & $186 / 200 / 208$ & $140 / 144 / 157$ \\
\hline Rero 11 & $103 / 103$ & $212 / 224$ & $130 / 148$ & $200 / 200$ & $157 / 157$ \\
\hline Kinsei & $103 / 105$ & $212 / 224$ & $134 / 172$ & $200 / 208$ & $140 / 157$ \\
\hline Ralls Janet & $105 / 126$ & $212 / 250$ & $148 / 148$ & $186 / 210$ & $140 / 140$ \\
\hline Starking Delicious & $103 / 105$ & $212 / 218$ & $148 / 172$ & $200 / 208$ & $144 / 157$ \\
\hline Orin & $103 / 103$ & $222 / 228$ & $130 / 134$ & $186 / 186$ & $140 / 140$ \\
\hline Kiou & $103 / 103$ & $222 / 224$ & $130 / 134$ & $186 / 186$ & $140 / 140$ \\
\hline Hatsuaki & $103 / 105$ & $224 / 228$ & $132 / 132$ & $186 / 200$ & $140 / 144$ \\
\hline Senshu & $103 / 105$ & $212 / 224$ & $130 / 148$ & $186 / 186$ & $140 / 140$ \\
\hline Mellow & $103 / 103$ & $222 / 224$ & $132 / 134$ & $186 / 186$ & $140 / 140$ \\
\hline Indo & $103 / 111$ & $212 / 228$ & $130 / 148$ & $186 / 186$ & $140 / 157$ \\
\hline Ranzan & $103 / 103$ & $212 / 254$ & $134 / 172$ & $186 / 208$ & $157 / 157$ \\
\hline Carolina Red June & $103 / 107$ & $252 / 254$ & $134 / 154$ & $186 / 200$ & $144 / 174$ \\
\hline Akane & $124 / 126$ & $228 / 250$ & $134 / 148$ & $186 / 186$ & $144 / 159$ \\
\hline Scarlet & $103 / 105$ & $212 / 212$ & $148 / 172$ & $186 / 200$ & $144 / 146$ \\
\hline \multirow[t]{2}{*}{ Yukari } & $105 / 111$ & $222 / 228$ & $132 / 132$ & $186 / 186$ & $144 / 146$ \\
\hline & \multicolumn{5}{|c|}{ SSR genotype (bp) } \\
\hline Cultivar & CH01d08 & CH02c09 & $\mathrm{CH} 05 \mathrm{a} 04$ & $\mathrm{CH02g04}$ & \\
\hline Golden Delicious & $248 / 270$ & $243 / 257$ & $166 / 195$ & $187 / 192$ & \\
\hline Akagi & $270 / 270$ & $243 / 259$ & $166 / 189$ & $187 / 191$ & \\
\hline Jonathan & $238 / 270$ & $249 / 257$ & $189 / 189$ & $191 / 191$ & \\
\hline Toko & $248 / 252$ & $243 / 243$ & $166 / 195$ & $187 / 192$ & \\
\hline Ambitious & $238 / 248$ & $233 / 243$ & $195 / 195$ & $192 / 192$ & \\
\hline Fuji & $238 / 252$ & $233 / 245$ & $189 / 195$ & $192 / 192$ & \\
\hline Hokuto & $238 / 252 /$ & $233 / 243 / 245$ & $189 / 195 /$ & $187 / 192 /$ & \\
\hline Rero 11 & $252 / 252$ & $243 / 255$ & $159 / 195$ & $187 / 192$ & \\
\hline Kinsei & $248 / 252$ & $243 / 245$ & $159 / 195$ & $187 / 192$ & \\
\hline Ralls Janet & $252 / 270$ & $233 / 257$ & $169 / 195$ & $191 / 192$ & \\
\hline Starking Delicious & $238 / 252$ & $245 / 255$ & $159 / 189$ & $192 / 192$ & \\
\hline Orin & $248 / 252$ & $243 / 243$ & $165 / 166$ & $192 / 192$ & \\
\hline Kiou & $238 / 248$ & $243 / 243$ & $166 / 195$ & $192 / 192$ & \\
\hline Hatsuaki & $270 / 270$ & $257 / 257$ & $189 / 195$ & $187 / 187$ & \\
\hline Senshu & $238 / 248$ & $233 / 243$ & $166 / 195$ & $192 / 192$ & \\
\hline Mellow & $248 / 270$ & $243 / 257$ & $195 / 195$ & $187 / 192$ & \\
\hline Indo & $252 / 252$ & $243 / 245$ & $165 / 195$ & $192 / 192$ & \\
\hline Ranzan & $248 / 252$ & $243 / 255$ & $159 / 166$ & $187 / 192$ & \\
\hline Carolina Red June & $252 / 268$ & $257 / 257$ & $169 / 189$ & $190 / 192$ & \\
\hline Akane & $238 / 292$ & $245 / 257$ & $181 / 189$ & $188 / 191$ & \\
\hline Scarlet & $252 / 252$ & $245 / 257$ & $169 / 195$ & $190 / 192$ & \\
\hline Yukari & $238 / 270$ & $257 / 257$ & $166 / 189$ & $187 / 191$ & \\
\hline
\end{tabular}

${ }^{2}$ Data are from Kitahara et al. (2005).

contents ['Starking Delicious'(S9S28), 'Senshu' (S1S7), 'Golden Delicious' (S2S3), and 'Ralls Janet' (SIS2)] (Table 2), and from their fruit and branch characteristics. All 38 alleles in 'Kinsei', 'Kiou', and 'Mellow' had been inherited from 'Golden Delicious' + 'Starking Delicious', 'Orin'+ 'Senshu', and '19Gou' + 'Golden Delicious', respectively, without discrepancy (Table 3), indicating that they are hybrids of those two cultivars (Table 4). These data were supported by the phenogram results (Fig. 1). In the case of 'Mellow', since we had no samples of '19Gou', we investigated 'Indo' and 'Golden Delicious' instead. In the case of 'Ranzan', two loci in 'Golden Delicious' (222 bp and 224 bp at CH02d08, and $140 \mathrm{bp}$ and $146 \mathrm{bp}$ at Ch01g05) and seven loci in 'Ralls Janet' (112 bp and 122 bp at $\mathrm{CHO2c02b,226} \mathrm{bp} \mathrm{at} \mathrm{CH} 03 \mathrm{~d} 07,105 \mathrm{bp}$ and $126 \mathrm{bp}$ at $\mathrm{CHO}$ b07, $134 \mathrm{bp}$ and $154 \mathrm{bp}$ at $\mathrm{CH} 01 \mathrm{~d} 09,140 \mathrm{bp}$ at $\mathrm{CH} 01 \mathrm{~g} 05,233$ bp and $257 \mathrm{bp}$ at $\mathrm{Ch02c09}$, and $169 \mathrm{bp}$ and 195 bp at Ch05a04) were not inherited by 'Ranzan'. Since one allele in each locus of 'Starking Delicious' was inherited by 'Ranzan' without discrepancy, 'Starking Delicious' seems to have been used as a maternal parent of 'Ranzan'. Although 'Golden Delicious' was excluded as the paternal parent of 'Ranzan', it was 
Table 4. Analyses of nine parent-offspring relationships in apple by S-RNase content and SSR loci.

\begin{tabular}{lll}
\hline Cultivar & \multicolumn{1}{c}{ Reputed parents } & \multicolumn{1}{c}{ Our results } \\
\hline Akagi & Golden Delicious x unknown & Golden Delicious x Jonathan \\
Ambitious & Toko x unknown & Toko x Fuji \\
Hokuto & Fuji x unknown & Fuji x Rero 11 \\
Kinsei & Golden Delicious x Ralls Janet & Golden Delicious x Starking Delicious \\
Kiou & Orin x Hatsuaki & Orin x Senshu \\
Mellow & 19Gou (Golden Delicious x Indo) x Indo & 19Gou x Golden Delicious \\
Ranzan & Starking Delicious x Carolina Red June & Starking Delicious x unknown \\
Scarlet & Akane x Starkin Delicious & Fuji x unknown, or unknown x Fuji \\
Yukari & McIntosh x Golden Delicious & Jonathan x Golden Delicious \\
\hline
\end{tabular}

suggested that a clone having the $S 2$-allele and closely related to 'Golden Delicious' might have been used as the paternal parent of 'Ranzan' based on the phenogram results (Fig. 1).

Previously, we could not find a paternal parent of 'Kotoku', since 'Delicious' and 'Starking Delicious' were excluded by $S$-RNase content or SSR analyses (Kitahara et al., 2005). From the phenogram results (Fig. 1), a clone having the $S 28$-allele and closely related to 'Delicious' and 'Starking Delicious' might have been used as the paternal parent of 'Kotoku'.

The breeding process of 'Scarlet' is as follows: 'Akane' was crossed with 'Starking Delicious' in 1970, selected in 1973, registered in 1984. The $S$-RNase content of 'Scarlet' (S3S9) by PCR-digestion analysis did not match any of the expected $S$-RNase contents from its supposed parents 'Akane' (S7S24) and 'Starking Delicious' (S9S28) (Table 2). As the $S$-genotype of 'Scarlet' was also confirmed by pollination tests (Matsumoto et al., 2003b), 'Akane' appeared not to have been used as the maternal parent of 'Scarlet'. Moreover, two loci within 19 SSR loci in 'Starking Delicious' (198 bp and 206 bp) at CH01f07a, and 159 bp and 189 bp at CH05a04) were not inherited by 'Scarlet', suggesting that 'Starking Delicious' was not the paternal parent of 'Scarlet' (Table 3). At least 'Fuji' seems to be related to the production of 'Scarlet' from its $S$-RNase content (S1S9), phenogram results (Fig. 1), and fruit and branch characteristics. Based on the SSR analysis, one allele in each locus of 'Fuji' was inherited by 'Scarlet' without discrepancy (Table 3), also supporting the likelihood that 'Fuji' was used as a maternal or a paternal parent of 'Scarlet' (Table 4). Although 'Starking Delicious' was excluded as a parent of 'Scarlet', a clone possessing the $S 28$-allele and closely related to 'Starking Delicious' that was unregistered during the breeding process might have been used as another parent of 'Scarlet', based on data of the $S$-RNase content (Table 2) and phenogram results (Fig. 1).

'Yukari' was produced by 'McIntosh' x 'Golden Delicious'. However, its $S$-RNase content $S 2 S 9$ by PCR-digestion analysis and pollination tests (Matsumoto et al., 2003b) did not match any of the expected $S$-RNase contents from its supposed parents, 'McIntosh' (S10S25) and 'Golden Delicious' (S2S3) (Table 2). From the 19SSR loci analysis, one allele in each locus of 'Golden Delicious' was inherited by 'Yukari' without discrepancy (Table 3), suggesting that 'Golden Delicious' was used as a paternal parent of 'Yukari'. These results suggested that 'McIntosh' had not been used as the maternal parent of 'Yukari'. 'Fuji' (S1S9) and 'Jonathan' (S7S9) were selected as the maternal parents of 'Yukari' from their $S$-RNase contents (Table 2), and fruit and branch characteristics. Seven loci within the 19 SSR loci in 'Fuji' (226 bp at $\mathrm{CH} 03 \mathrm{~d} 07,158 \mathrm{bp}$ and $160 \mathrm{bp}$ at $\mathrm{CH} 01 \mathrm{c} 06,178 \mathrm{bp}$ and 206 bp at CH01f07a, 212 bp at CH02d08, 148 bp at CH01d09, 233 bp and 245 bp at $\mathrm{CHO} 2 \mathrm{c09}$, and 192 bp at $\mathrm{CH} 02 \mathrm{~g} 04$ ) were not inherited by 'Yukari', while all 38 alleles except one (134 bp at CH01d09) in 'Yukari' had been inherited from 'Jonathan' and 'Golden Delicious' without discrepancy (Table 3). Homozygous $132 \mathrm{bp}$ and $134 \mathrm{bp}$ at CH01d09 in 'Yukari' and 'Jonathan', respectively, might be heterozygous, one with a null allele. These results strongly suggested that 'Yukari' was a hybrid of 'Jonathan and 'Golden Delicious', a probability supported by the phenogram results (Fig. 1).

\section{Literature Cited}

Bowers, J., J.-M. Boursiquot, P. This, K. Chu, H. Johansson, and C. Meredith. 1999. Historical genetics: The parentage of Chardonnay, Gamay, and other wine grapes of northeastern France. Science 285:1562-1565.

Bowers, J.E. and C.P. Meredith. 1997. The parentage of a classic wine grape, Cabernet Sauvignon. Nature Genet. 16:84-87.

Broothaerts, W., G.A. Janssens, P. Proost, and W.F. Broekaert. 1995. cDNA cloning and molecular analysis of two self-incompatibility alleles from apple. Plant Mol. Biol. 27:499-511.

de Nettancourt, D. 1977. Incompatibility in angiosperms, p. 28-57. In: R. Frankel, G.A.E. Gal, and H.F. Linskens (eds.). Monographs on theoretical and applied genetics. Springer-Verlag, Heidelberg, Germany.

Gianfranceschi, L., N. Seglias, R. Tarchini, M. Komjanc, and C. Gessler. 1998. Simple sequence repeats for the genetic analysis of apple. Theor. Appl. Genet. 96:1069-1076.

Guilford, P., S. Prakash, J.M. Zhu, E. Rikkerink, S. Gardiner, H. Bassett, and R. Forster. 1997. Microsatellites in Malus $\times$ domestica (apple): Abundance, polymorphism and cultivar identification. Theor. Appl. Genet. 94:249-254.

Gupta, P.K., H.S. Balyan, P.C. Sharma, and B. Ramesh. 1996. Microsatellites in plants: A new class of molecular markers. Curr. Sci. 70:45-54.

Hemmat, M., N.F. Weeden, and S.K. Brown. 2003. Mapping and evaluation of Malus $\times$ domestica microsatellites in apple and pear. J. Amer. Soc. Hort. Sci. 128:515-520.

Hokanson, S.C., W.F. Lamboy, A.K. Szewc-McFadden, and J.R. McFerson. 2001. Microsatellite (SSR) variation in a collection of Malus (apple) species and hybrids. Euphytica 118:281-294.

Hokanson, S.C., A.K. Szewc-McFadden, W.F. Lamboy, and J.R. McFerson. 1998. Microsatellite (SSR) markers reveal genetic identities, genetic diversity and relationships in a Malus $\times$ domestica Borkh. core subset collection. Theor. Appl. Genet. 97:671-683.

Janssens, G.A., I.J. Goderis, W.F. Broekaert, and W. Broothaerts. 1995. A molecular method for $S$-allele identification in apple based on allele-specific PCR. Theor. Appl. Genet. 91:691-698.

Kimura, T., Y. Sawamura, K. Kotobuki, N. Matsuta, T. Hayashi, Y. Ban, and T. Yamamoto. 2003. Parentage analysis in pear cultivars characterized by SSR markers. J. Jpn. Soc. Hort. Sci. 72:182-189.

Kitahara, K. and S. Matsumoto. 2002a. Sequence of the $S_{10}$ cDNA from 'McIntosh' apple and a PCR-digestion identification method. HortScience 37:187-190. 
Kitahara, K. and S. Matsumoto. 2002b. Cloning of the $S_{25}$ cDNA from 'McIntosh' apple and an $S_{25}$-allele identification method. J. Hort. Sci. Biotechnol. 76:163-166.

Kitahara, K., S. Matsumoto, T. Yamamoto, J. Soejima, T. Kimura, H. Komatsu, and K. Abe. 2005. Parent identification of eight apple cultivars by S-RNase analysis and simple sequence repeat markers. HortScience 40:314-317.

Kitahara, K., J. Soejima, H. Komatsu, H. Fukui, and S. Matsumoto. 2000. Complete sequences of the S-genes, Sd- and Sh-RNase cDNA in apple. HortScience 35:712-715.

Liebhard, R., L. Gianfranceschi, B. Koller, C.D. Ryder, R. Tarchini, E. Van De Weg, and C. Gessler. 2002. Development and characterization of 140 new microsatellites in apple (Malus $\times$ domestica Borkh.). Mol. Breeding 10:217-241.

Liebhard, R., B. Koller, L. Gianfranceschi, C. Gessler. 2003. Creating a saturated reference map for the apple (Malus $\times$ domestica Borkh.) genome. Theor. Appl. Genet. 106:1497-1508.

Maliepaard, C., F.H. Alston, G. van Arkel, L.M. Brown, E. Chevreau, F. Dunemann, K.M. Evans, S. Gardiner, P. Guilford, A.W. van Heusden, J. Janse, F. Laurens, J.R. Lynn, A.G. Manganaris, A.P.M. den Nijs, N. Periam, E. Rikkerink, P. Roche, C. Ryder, S. Sansavini, H. Schmidt, S. Tartarini, J.J. Verhaegh, M. Vrielink-van Ginkel, and G.J. King. 1998. Aligning male and female linkage maps of apple (Malus pumila Mill.) using multi-allelic markers. Theor. Appl. Genet. 97:60-73.

Martinez-Gomez, P., S. Arulsekar, D. Potter, and T.M. Gradziel. 2003. Relationships among peach, almond, and related species as detected by simple sequence repeat markers. J. Amer. Soc. Hort. Sci. 128:667-671.

Matsumoto, S., S. Komori, K. Kitahara, S. Imazu, and J. Soejima. 1999a. S-genotypes of 15 apple cultivars and self-compatibility of 'Megumi'. J. Jpn. Soc. Hort. Sci. 68:236-241.

Matsumoto, S., K. Kitahara, S. Komori, and J. Soejima. 1999b. A new $S$-allele in apple ' $S g$ ', and its similarity to the ' $S f$ ' allele from Fuji. HortScience 34:708-710.

Matsumoto, S. and K. Kitahara. 2000. Discovery of a new self-incompatibility allele in apple. HortScience 35:1329-1332.

Matsumoto, S., Y. Furusawa, H. Komatsu, and J. Soejima. 2003a. S-allele genotypes of apple pollenizers, cultivars and linages including those resistant to scab. J. Hort. Sci. Biotechnol. 78:634-637.

Matsumoto, S., K. Kitahara, Y. Furusawa, J. Soejima, H. Komatsu, and H. Fukui. 2003b. S-allele genotype of apple cultivars and selections. Acta Hort. 622:389-396.

Nei, M. 1972. Genetic distance between populations. Amer. Naturalist 106:283-292.

Rohlf, F.J. 2000. NTSYS-pc, Numerical taxonomy and multivariate analysis system, Version 2.1. Exeter Publ., Setauket, N.Y.

Sakurai, K., S.K. Brown, and N.F. Weeden. 1997. Determining the self-incompatibility alleles of Japanese apple cultivars. HortScience 32:1258-1259.

Sakurai, K., S.K. Brown, and N. Weeden. 2000. Self-incompatibility alleles of apple cultivars and advanced selections. HortScience 35:116-119.

Sefc, K.M., H. Steinkellner, J. Glossl, S. Kampfer, and F. Regner. 1998. Reconstruction of a grapevine pedigree by microsatellite analysis. Theor. Appl. Genet. 97:227-231.

Sefc, K.M., H. Steinkellner, H.W. Wagner, J. Glossl and F. Regner. 1997. Application of microsatellite markers to parentage studies in grapevine. Vitis 36:179-183.

Soejima, J., K. Abe, N. Kotoda, and H. Kato. 2000. Recent progress of apple breeding at the apple research center in Morioka. Acta Hort. 538:211-214.

Testolin, R., T. Marrazzo, G. Cipriani, R. Quarta, I. Verde, M.T. Dettori, M. Pancaldi, and S. Sansavini. 2000. Microsatellite DNA in peach (Prunus persica L. Batsch.) and its use in fingerprinting and testing the genetic origin of cultivars. Genome 43:512-520.

Thomas, M., S. Matsumoto, P. Cain, and N.S. Scott. 1993. Repetitive DNA of grapevine: Class present and sequences suitable for cultivar identification. Theor. Appl. Genet. 86:173-180.

Verdoodt, L., A. Van Haute, I.J. Goderis, K. De Witte, J. Keulemans, and W. Broothaerts. 1998. Use of the multi-allelic self-incompatibility gene in apple to assess homozygocity in shoots obtained through haploid induction. Theor. Appl. Genet. 96:294-300.

Yamamoto, T., K. Mochida, T. Imai, T. Haji, H. Yaegaki, M. Yamaguchi, N. Matsuta, I. Ogiwara, and T. Hayashi. 2003. Parentage analysis in Japanese peaches using SSR markers. Breeding Sci. 53:35-40. 